\title{
A MORE BREAST MILK-LIKE INFANT FORMULA REDUCES EXCESSIVE BODY FAT ACCUMULATION IN ADULT MICE
}

\author{
A. Oosting, E. Engels, D. Kegler, M. Abrahamse, I. Teller, E. van der Beek
}

Baby Food Division, Danone-Research-Centre for Specialised Nutrition, Wageningen, The Netherlands

We previously showed a sustained effect of fatty acid composition of postnatal diet on fat mass accumulation in adult mice ${ }^{1}$. Now, we investigated another aspect of lipid quality: the lipid matrix. In contrast to infant formula (IF), fat globules in breast milk (BM) are up to ten times larger and coated with a phospholipid membrane. Our new concept IF with a complex lipid matrix $\left(\right.$ Nuturis ${ }^{\circledR}$ ) contains lipid droplets with physical properties closer to BM globules. In the present study we evaluated long term effects of Nuturis ${ }^{\circledR}$ on body composition in mice.

From postnatal day (PN) 16 to 42, male C57Bl/6j mice were fed with either Nuturis ${ }^{\circledR}$ or standard IF (CTR). Subsequently, mice were challenged with a moderate Western style diet (WSD; 20w\% fat) until PN98. Nonchallenged mice raised on CTR and standard chow served as reference. Body composition was monitored and visceral and subcutaneous fat depots were analysed at PN98.

Adult body weight as well as total, visceral and subcutaneous fat mass of the Nuturis ${ }^{\circledR}$ group were lower than CTR and closer to the reference. This was entirely due to reduced fat accumulation since lean body mass was similar in both groups. These findings confirm the protective effect of CLM on adult body composition ${ }^{2}$.

In conclusion, the more BM-like lipid matrix $\left(\right.$ Nuturis $\left.^{\circledR}\right)$ in early life prevents excessive fat accumulation in an obesogenic adult environment.

Ref: ${ }^{1}$ Oosting et al., 2010, Pediatric Research 68(6): 494-499; ${ }^{2}$ Oosting et al., 2010, Power of Programming conference, Munich 